statis.html 2) 自動車工業会 統計月報, http:// www.jama. or.jp/stats/ m_report/index.html 3) 潤滑経済編集部, 潤滑経済, 518,2 4 4) 足立 之彦, 潤滑経済, 507, 10 5) 佐藤維榣, 润滑経済, 518, 42 6) 木幡隆男 , 潤滑経済, 518,48 7) 安齋享征, 潤滑経済, 518,53 8) 佐野弘, 潤滑経 済, 518,589 9) 中央環境審議会, 今後の自動車排出ガス低隇対策のあり方 について (第九次答申)，平成20年 1 月 29 日 10) 浜口仁, 潤滑経済, 507, 2 11）山下幸人,トライボロジスト, 53, 443 12) Devlin, M. T., et al., Lub.Sci., 20, 151 13) Gangopadhyay, A. K., et al., Lub.Sci., 20,163 14) 八 木下和宏ら，自動車技術会論文集，39，347 15） Devlin, M. T., et al., SAE Paper, 2008-01-2460 16)Guevremont, J. M., et al., Trib. Trans., 51, 324 17) Yoshida, S., et al., SAE Paper, 2008-01-2480 18) Mitarai, A., et al., SAE Paper, 2008-32-0005 19) Yaguchi, An et al., SAE Paper, 2008-32-0080 20) Fukuda, K., et al., SAE Paper, 2008-01-2494 21) Devlin, C. C., et al., SAE Paper, 2008-01-2375 22）波岸俊哉ら,出光トライボレビュー,31, 1929 23）平原祐, 日本マリンエンジニアリング学会誌, 43, 830 24）小林正則 ら, 日本マリンエンジニアリング学会誌, 43, 176 25) 田中承允, 日本マ リンエンジニアリング学会誌, 43, 170 26）藤田裕, トライボロジスト, 53, 45627$)$ 野城陽子ら, 自動車技術, 62, 70 28) 佐光佳仁, 潤滑経済, 507, 20 29) Newcomb, T, et al., SAE Paper, 2008-01-2395 30）青山健 治, 出光技報, 51, 27 31） Narita, K., et al., Proc. Inst. Mech. Eng., 222(J3), 343 32) Manabe, Y. et al,, Tribology Online, 3, 153 33) 山崎正典ら, 自動 車技術会論文集, 39, 287 34) 藤田裕, 月刊トライボロジー, 254, 42 35) Tersigni, S. H., et al., SAE Paper, 2008-01-2397 36$)$ 安藤淳二ら, 自動車技 術, 62, 8637 ) 大見康生, フルードパワーシステム, 39, 261 38) 小西晃 子ら,フルードパワーシステム, 39, 27239 篠田実男ら, 出光技報, 51 , 168 40) Kalin, M., et al., Trans. ASME J.Tribol,, 130, 011013-1 41) 大関浩 , 自動車技術, 62, 7542 ) 森正継ら, 精密工学会誌, 74,539 43) Martins, R., et al, Proc. Inst. Mech. Eng., 222(J3), 431 44) 下田修吉, 潤滑経済, 512, $3845)$ 金子正人ら, 出光トライボレビュー, 31, 1955 46)時合健生ら, 出光技報, 51, 3547 ）須田聡, トライボロジスト, 53,10 48）関川岳ら , 自動車技術, 62, 96 49）梖山正, トライボロジスト, 53, 33 50) Wakabayashi, T., et al., J.Jpn. Petrol. Inst., 51, 134 51) 紐川晃ら, 精密工学会 誌, 74, 108052$)$ 植山正ら, 砥粒加工学会誌, 52, 525 53）系魚川文広, 潤滑経済, 508, 254 )中村隆ら, 砥粒加工学会誌, 52, 569 55)細田貢司, 潤滑経済, 508, 16 56) 浦部崇ら,出光トライボレビュー,31, 1959 57) 小田喜敏美ら，砥粒加工学会誌，52, 583 58）Dasch, J. M., et al., Trib.Trans, 51, 381 59）堂田邦明ら, 塑性と加工，49, 1047 60）山本修太郎ら, 機 械学会論文集 C, 74, 978 61）長瀬直樹ら,鉄と鋼, 94, 429 62）長瀬直 樹ら,鉄と鋼, 94, 415 63）柴田潤一, トライボロジスト, 53,437 64) 小別所匡寛ら, 出光トライボレビュー,31, 1963 65）本山忠昭ら, 防錆管 理, 52,45 66) 清水良直, 防錆管理, 52, 325 67) 三上英信, トライボロ ジスト, 53, 248 68)Coe, C., et al., NLGI Spokesman, 72(8), 22, 69)Sivik, M. R., et al., NLGI Spokesman, 72(8), 9 70) Faci, H., et al., NLGI Spokesman, 72(5), 15 71) Ward, W. C., et al, NLGI Spokesman, 72(1),21 72) 北野浩之ら, 出 光トライボレビュー, 31, 1967 73) Miklozic, K. T., et al., Wear, 265, 1893 74) Matta, C., et al., Lub. Sci, 20, 137 75) Kubo, T., et al., Wear, 265, 461 76) Minami, I., et al., Tribol. Lett., 30, 215 77) Minami, I., et al., J. Synth. Lubr., 25, 45 78) Fox, M. F., et al., Proc. Inst. Mech. Eng., 222 (J3), 291 79) Peterangelo, S. C., et al., J. Synth. Lubr., 25, 31

\section{6 石油類似資源}

\section{1. 開発の動向}

(1)オイルサンド

昨年は前半には石油価格の高騰により重質油開発が活発で あったが, 後半は金融危機に伴う原油価格の暴落が重質油開 発に大きく影響した。オイルサンドや超重質油の採算コスト は30〜40ドル/バレルと見られており，原油価格暴落により 資本回収期間の見直しが必要となったため列といわれている。

カナダのオイルサンド開発では昨年前半には British Petroleum社, Occidental Petroleum社がオイルサンド開発を再開す るという動きがあり，開発は一段と加速するかに見えた2〉。し かし，10月以降は開発費用のかさむ改質装置の開発計画にお いて Shell, Imperial Oil, Petro-Canada 社などの建設の延期や Total社の建設中止などが発表された。一方Husky社のように 予定通りの開発を続けるところもある4。

オイルサンド開発には多くの環境問題が指摘されているが, $\mathrm{CO}_{2}$ 問題もその一つで，オイルサンド回収のための熱源を天然 ガスからビチュメンのコーキングで生成したコークのガス化 に切り替える計画がある。これはガス化により発電, 水素製 造を行うだけでなく生成した $\mathrm{CO}_{2}$ の地下貯留も含んでいる。 カナダ・アルバータ州政府はCCS 推進のための財政支援を行 い, 2015 年までに 500 万トンの $\mathrm{CO}_{2}$ 排出量削減を見込んでい $る^{5 \dagger}$ 。また，水源の保護と流域管理を改善し生活用水の保護政 策を推し進めている。

\section{(2)超重質油}

ベネズエラでは国営石油会社（PDVSA）を中心に行われて きたオリノコベルトの埋蔵量評価がほぼ終了した。一方，外 国資本による油田開発はPDVSAとのジョイントベンチャー化 を進めてきたが，2008年はこの方針をサービス会社にも適用 する計画があり，開発は停膟すると予想されている6。

(3) オイルシェール

2008年度前半の原油価格高騰でオイルシェールも見直され た。現在中国，エストニア，ブラジルに稼動中のプロセスが あるが, シェールオイル生産量は 100 万トン未満である。こ れが 2015 年までには 3500 万トンまで増加すると予想されて いる7。10月には28th Oil Shale Symposium が米国 Colorado School of Mines (CSM) で開催され，開発の現状が報告された。 米国では Total, Shell, ExxonMobil の出資でCSM の監督下 に Center for Oil Shale Technology and Research (COSTAR) という研究機関が設立された。政府からの土地の貸与も進め られている。しかし, 環境影響評洒やインフラ整備が追いつ かないため，これらの政策が性急過ぎるとの声もある81。

世界最大のオイルシェール資源のある米国西部では, Shell 社の ICP 法（地下乾留法）と Oil Shale Exploration 社 (OSEC) の地上乾留法の 2 つのプロジェクトが行われている。地上乾 留法は2013年にブラジルの Petrosix 型乾留炉による生産を前 
提に事業化調査が開始され，日本から三井物産が参画するこ とが発表された ${ }^{9 !} 。$

ヨルダンは開発に意欲を示しており，9月にTotal社/ペト ロブラス社と，12月にShellとの契約を結んだ。ヨルダンには 他にロシア，中国，エストニアが興味を示している ${ }^{10)}$ 。

モロッコではTotal 社が開発を目指した調査を継続中であ る。中国は撫順のオイルシェールでは $100 \mathrm{t} の$ 乾留炉で行って いるが，粉体用にATP プロセスを導入した ${ }^{111}$ 。

\section{2. 研究の動向}

(1)オイルサンドおよび超重質油

カナダではCSSやSAGD法の熱源として従来の天然ガスに 代わり，ビチュメンからのコークを利用した熱，電力，水素 の製造と発生する $\mathrm{CO}_{2}$ の CCSが検討されており，その経済性 評価が報告されている ${ }^{12 \dagger}$ 。また，水の使用量を削減するため SAGD や CCS の改良やVAPEX パイロットテストなども行わ れた ${ }^{13)}$

我が国では石油産業活性化センターに扔いて超臨界水を用 いた超重質油・オイルサンド油等の活用技術の開発が続けら れている。

(2)オイルシェール

米国では ICP 法の技術的概要の紹介とそれに基づくエネル ギー収支, $\mathrm{CO}_{2}$ 排出量の LCA が行われ，ICP 法では投入工ネ

2. 石

\section{1 石炭資源開発技術}

石炭は，生産国の輸送インフラ整備の遅れ等による供給制 約，油脂燃料や資機材価格の高騰等による生産コス卜上昇，資 源技術者不足などの構造的な問題に加え，採掘に伴う地域環 境対策と地球温暖化ガスでもある炭鉱メタンガス回収利用な どの地球環境対策，並びに奥部化・深部化による採掘条件の 変化などが安定供給の制約要因となっている。また，世界的 な需要低迷による新規投資の減少は将来の供給ポテンシャル 低下への䯚念材料である。

\section{1. 石炭資源探査技術分野}

(1) 日本・インドネシア石炭資源解析調査

2004年度に開始した本事業は，現地政府機関と共同で南ス マトラおよび東・南カリマンタン地域において GIS ベースの 石炭資源の総合的な解析・評価システム構築を行ってきた。 2008 年度はデー夕作成および公開用システムを完成させた。 現地においてインドネシア側システム管理者・オペレータ候 補者を対象にシステム操作訓練を行い，2009年 3 月には現地
ルギーの $1.2 \sim 1.5$ 倍のエネルギーが回収される一方, 従来の 原油生産に比べ, $\mathrm{CO}_{2}$ 排出量は $21 \sim 47 \%$ 増加すると予想され た ${ }^{14\rangle}$ 。また，オイルシェールの $\mathrm{CO}_{2}$ 貯蔵能力の研究が紹介さ れた ${ }^{15)}$ 。中国では撫順のシェールオイルから化学原料と燃料

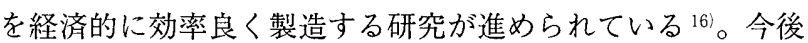
は油回収率向上の他, 化学原料化, 地下乾留法のプロセス化 関連， $\mathrm{CO}_{2}$ の CCS 関連の研究が増加するであろう。

\section{文 献: References}

1）伊原 賢,JOGMEC 石油天然ガス資源情報 2008/08/05, http://oilgas-

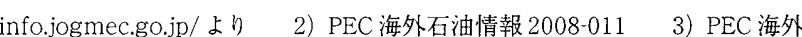

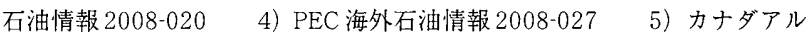
バータ州オイルサンド産業の最新動向 WINTER 2008/2009 6) 船木, 石 油・天然ガスレビュー,42,69 7) Proceedings of the Eighteenth International Offshore and Polar Engineering Conference, p. 19 8) Boak, J., Oil Shale, 25, 393 9) 三井物産ホームページより 10) 新日石総研，世界の エネルギーの話題（2008 年 9 月 8 日）, http://www.eneos-sohken.co.jp/library/files/20080908_web.pdfより 11 1) Qian, J., Oil Shate, 25, 487 12) Nourouzi-Lavasani,S., Ind. Eng.Chem.Res., 47, 7118 13）田中浩之，他，石 油・天然ガスレビュー, 43, 63, 2009 14）Brandt, A. R.. Environ.Sci.Technol., 42, 7489 15) Busch, A., et al,, Int. J. Greenhouse Gas Control, 2, 297 16) Yan, F., et al., Energy Sources, Part A, 30, 1242

岸

政府・企業関係者や本邦企業への成果報告会を実施した。

（2)ベトナム・クアンニン（Quang Ninh）プロジェクト 本事業は，ベトナム石炭鉱物産業集団 (VINACOMIN) とク アンニン地域の深部共同探査を実施し, 石炭資源量, 地質構 造把握を目的とする。2008 年度は精査区域として選定した ケーチャム地域に扔いて, 試錐探査 ( 2 本, 孔長 $1,600 \mathrm{~m})$, デー 夕解析を実施すると共に, 総合解析と成果図作成等のデー夕 整備，無煙炭市場調査を実施した。また，ケーチャム地区で の深部坑内炭鉱開発の概念設計を実施した。

（3）モンゴル・東ゴビ（Gov）プロジェクト

産業貿易省 MIT（Ministry of Industry and Trade）と高品質 石炭の潜在的な供給ポテンシャルが予想される東ゴビ地域で 広域 $\left(12\right.$ 万 $\left.\mathrm{km}^{2}\right)$ 共同探査を実施している。2008 年度は過去 2 年間に実施した調査地域から，開発ポテンシャルが高い Khoot地域を選定し，詳細調査が行われ，試錐調査を中心に物 理探査，地表踏査，石炭分析などが実施された。 